\title{
CHRONIC TOXICITY TEST WITH SEA URCHIN Echinometra lucunter AND Lytechinus variegatus (ECHINODERMATA: ECHINOIDEA), EXPOSED TO LIGHT-STICK - FLAG PATERNOSTER USED FOR LONGLINE SURFACE FISHING
}

\author{
Caio Cesar-Ribeiro ${ }^{I}$ and Maria Fernanda Palanch-Hans \\ Centro Universitário Monte Serrat - UNIMONTE \\ Laboratório de Ecotoxicologia
}

(Av. Rangel Pestana, 99, Vila Mathias, 11013-931 Santos, SP, Brasil)

1caio.ribeiro@unimonte.br

\begin{abstract}
In this work, the chronic toxicity of a mixture of light-stick chemicals and water was tested. The light-stick is used in fishery activities to catch swordfish. The tubes were collected on the beaches of the Costa dos Coqueiros - BA, Brazil, in the period from 14th to 31st July 2007. The method used was a short chronic toxicity test where embryos of the sea urchins Echinometra lucunter and Lytechinus variegatus were exposed to a stock solution consisting of the supernatant formed from a mixture of sea water and the orange-colored light-stick chemical. After a preliminary test, concentrations defined were $0.002,0.003,0.01,0.02,0.1,1.0 \%$ of stock solution. The final test ran for 36 hours for $E$. Lucunter and 24 hours for $L$. variegatus with 4 replicates for each concentration. The value of EC50 - 36h was $0.062 \%$ with confidence limits ranging from 0.042 to $0.079 \%$ and the EC50 - 24h was $0.011 \%$ with confidence limits ranging from 0.009 to $0.014 \%$, i.e., the chemical mix present in the light-stick is potentially toxic. So, as these flags are commonly used for fishing there is potential danger in their disposal in the open ocean.
\end{abstract}

\section{RESUMO}

O objetivo deste trabalho foi avaliar a toxicidade crônica da água do mar em contato com o líquido contido no light-stick, sinalizador utilizado em pesca de espinhel de superfície para a captura de espadarte. Os tubos foram coletados nas praias da Costa dos Coqueiros - BA, no período de 14 a 31 de Julho de 2007. O método utilizado para a verificação da toxicidade crônica foi o teste de curta duração com embriões de ouriço-do-mar Echinometra lucunter e Lytechinus variegatus, os ensaios foram realizados com solução estoque que consiste do sobrenadante formado a partir de uma mistura de água do mar com o líquido do sinalizador de coloração laranja. Após um teste preliminar as concentrações definidas foram $0.002 ; 0.003 ; 0.01 ; 0.02 ; 0.1 ; 1.0 \%$. O teste definitivo teve duração de 36 horas para $E$. lucunter e 24 horas para $L$. variegatus, sendo preparadas 4 réplicas para cada concentração. O valor da CE50 - 36h encontrado foi de $0.062 \%$ com limites de aceitabilidade variando de 0.042 a $0.079 \%$ e a CE50 - 24h encontrada foi de $0.011 \%$ com limites de aceitabilidade variando de 0.009 a $0.014 \%$, ou seja, os compostos químicos presentes no light-stick são potencialmente tóxicos. Portanto já que esses sinalizadores são utilizados comumente como petrechos de pesca há a necessidade de que eles sejam recolhidos, pois podem causar efeitos adversos quando abrem nos oceanos.

Descriptors: light-stick, Marine pollution, Ecotoxicology, Sea urchin.

Descritores: light-stick, Poluição marinha, Ecotoxicologia, Ouriço-do-mar.

\section{INTRODUCTION}

Among the great variety of fishing equipment currently in use in Brazil, the pelagic longline, which has been used since 1956 in the northeast region by the Japanese tuna fishermen (AZEVEDO et. al., 1999), is noteworthy. The equipment used nowadays consists of a main fishing line called the "longline" made of nylon

(*) Paper presented at the Symposium on Oceanography, 4., 2008, São Paulo, IOUSP. microfilament, to which are coupled secondary fishing lines bearing fishhooks, on which a specific bait for each kind of capture may be used. For example, for the capture of the swordfish Xiphias gladius, present in surface waters, a light attractor (light-stick) is used for night fishing (AMORIM; ARFELLI, 1984; AMORIM et. al., 1998).

The light-stick emits light, resulting from a chemilluminescent reaction between two components that are kept separate by a glass ampoule but such that when the tube is bend, the glass ampoule breaks mixing an ester-oxalate (trichlorosalicilate derivative) with hydrogen peroxide. The light shines for 48 hours. 
This process is catalyzed by fluorescent polycyclic aromatic hydrocarbons (9,10 diphenyllanthracene, perylene, rubrene) and the chemical reaction takes place in the presence of a highly viscous solvent (generally di-n-butylphthalate) (STEVANI; BAADER, 1999).

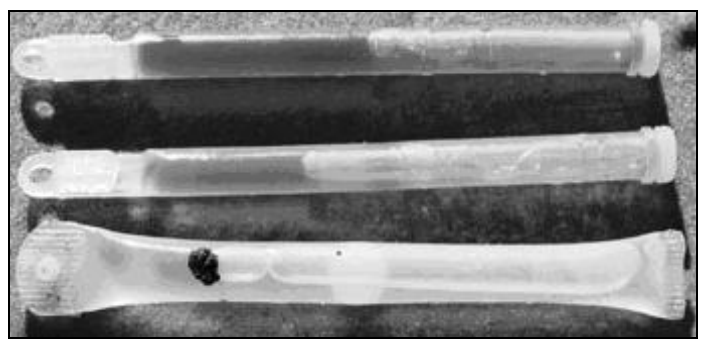

Fig. 1. Light-sticks found on the Costa dos Coqueiros, BA. Photo: Fabiano Prado Barreto.

The presence of light-sticks in the marine environment can lead to the accidental capture of marine turtles that are attracted by the light emitted by them (WANG et al., 2007). Besides, the light-sticks that are discharged in the oceans may continue to circulate in the seas as a solid residue that can be eaten by sea birds or even fish, creating a gastrointestinal obstruction and leading to many other hormonal and reproductive complications. (SHAW; MAPES, 1979; WEHLE; COLENAN, 1983; FURNESS, 1985; AZZARELLO; VLEET, 1987).

When the light-stick arrives on inhabitated shores, the local population, with little knowledge, can use the liquids in the tube as suntan lotion or to try to cure diseases such as rheumatism, vitiligo and mycoses.

The attractors can, further, have their packing broken in the ocean and have a direct effect on the marine environment, because of the discharge of the many toxic products present in their construction. According to the literature, the toxicity of the liquid in the attractors has been tested on winstar rats (IVAR DO SUL, et al., 2007), and with citotoxicity tests (BAGATTINI et al., 2006), but only one test has been carried out on marine organisms, resulting in acute toxicity and the development of cysts of Artemia sp. (PINHO et al., 2009).

With a view to contributing to the understanding of the toxic effect of the light-stick in the marine environment, this study simulated the breaking of the housing of the light-sticks in the marine environment and evaluated the chronic toxicity of the seawater that remains with the liquid in the light-stick by biotests of short duration of the contact of embryos of sea urchins of various species.

\section{Material and Methods}

With the support of the German NGO Global Garbage, a scientific hike was undertaken during the period from 14 to 31 July 2007, along almost $200 \mathrm{~km}$ of the beach of Costa dos Coqueiros, Bahia, where around 2554 tubes of luminous attractors were collected, about $34 \%$ of which were open and $63 \%$ had an orange color. The tubes were taken to the Laboratory of Ecotoxicology in UNIMONTE, Santos SP, where they were opened and used to prepare the stock solution to be used in the toxicity tests. The light-sticks have a greater density than water, because of the presence of the solvent di-n-butylphthalate and in the mixture of which there are some substances that are soluble in water and others that are hydrophobic. The preparation of the stock substances was made in such a way as to attempt to simulate the arrangement of the hydrophilic compounds in the water column; thus was prepared a homogenized mixture of the oil with sea water collected in the Laje de Santos region, in the proportion 1:1. Then the mixture was centrifuged for one minute, resulting in a watery fraction that was in contact with the liquid inside the light-stick. This watery fraction is the stock solution $100 \%$ (SE 100\%).

The toxicity of the sample was determined by a short duration chronic toxicity test made with the sea urchins Echinometra lucunter Linnaeus, 1758 and Lytechinus variegatus Lamarck, 1816 (ECHINODERMATA: ECHINOIDEA), through the sea urchin embryos exposure for $36 \mathrm{~h}$ and $24 \mathrm{~h}$, respectively, to different test concentrations obtained from the stock solution (SE100\%). At the end of the exposure the embryo-larval development was assessed. The larvae that presented abnormalities or late development were considered abnormal. The methodology was adapted from Prósperi and Araújo (2002). The tests were made at a temperature of $25^{\circ} \pm$ $1{ }^{\circ} \mathrm{C}$, with a photoperiod of 12 hours light and 12 dark.

A preliminary test was made with the test concentrations of $0.001,0.01,0.1,1.0$ and $10.0 \%$, obtained from the stock solution (SE 100\%), to establish the concentration to be used in the definitive test.

The definitive test was undertaken with the test concentrations of $0.002,0.003,0.01,0.02,0.1$ and $1.0 \%$, made from SE $100 \%$. Four replicates were made for each concentration. A parallel test was made with the reference substance Dodecil Sodium Sulphate (DSS) to ascertain the sensibility of the lot evaluated.

The EC50 - 36h was calculated by the Trimmed Spearman-Karber statistical method (HAMILTON et al., 1977). 


\section{RESULTS}

The value of EC50-36h found after the exposure of the sea urchin embryo to the test concentrations was $0.062 \%$ of stock solution $(0.042-$ $0.079 \%$ ) for E. Lucunter and the value of EC50-24h found was $0.011 \%(0.009-0.014 \%)$ for $L$. variegatus. The percentage values of undeveloped larvae are given in figure 2, where it may be seen that in the first concentration the light-stick is already toxic. The sensitivity of the lot of organisms used in the test was observed with the use of the reference substance DSS, the EC50- 36h being of $2.73 \mathrm{mg} / \mathrm{L}$ of DSS $(2.41-3.1$ $\mathrm{mg} / \mathrm{L})$ and the EC50- $24 \mathrm{~h}$ of $2.29 \mathrm{mg} / \mathrm{L}$ of DSS (1.98 $2.6 \mathrm{mg} / \mathrm{L}$ ), showing that the lot evaluated was within the limits of acceptability established by Resgalla Junior and Laitano (2002).

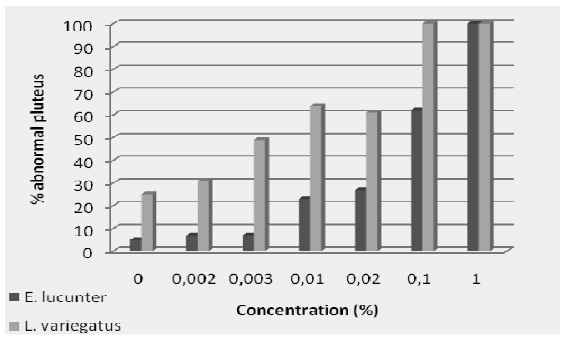

Fig. 2. Chronic toxicity of light-stick in contact with sea urchin embryos Echinometra lucunter and Lytechinus variegatus. The data represent the percentage of underdeveloped and/or deformed (abnormal) larvae pluteus by exposure concentration.

\section{DisCUSSION}

The data presented show that the liquid in the orange attractors releases contaminating substances into the water when the attractors are opened. These substances also have destructive effects on the development of the embryos and larvae of the sea urchin, especially on those of Lytechinus variegatus which showed greater sensitivity than Echinometra lucunter.

Little is known about the behavior of the chemical elements present in the construction of the light attractors, either when in contact with the sea water or after long periods of exposure to the sun, however research has shown that the main compound present in the light-sticks may be divided into three main categories: the fuel that generates energy for the chemiluminescent reaction (oxalate ester), the luminous substances (e.g. fluorescent hydrocarbons ester) and the solvent that will facilitate the reaction (usually di-n-butylphthalate).

The chemiluminescent reaction occurs in the presence of hydrogen peroxide and represents around
$30 \%$ of the content of the light-stick. As it is an oxygen reactive substance (ORS), it can have oxidative effects both on the cellular and supra molecular levels (STOREY, 1996), increasing the enzymatic activity of the peroxide that catalyzes the reduction of peroxides (ULIANA et al. 2008). In this present research project, the concentration of hydrogen peroxide in the stock solution prepared was not quantified, however because of its characteristics, the presence of this compound in a liquid environment can provoke cellular energy wastage, that has as a consequence a delay in the development of the pluteus-larva of the sea urchin. The chronic effect of hydrogen peroxide has already been evaluated on Cladocera, showing xenobiotic activity (MEINERTZ et. al., 2008).

Polycyclic Aromatic Hydrocarbonates (PAH) present in liquids also have toxic effects, because of their subcarcinogenic and mutagenic capability (BOFFETTA et. al., 1997; WHO, 1988), making essential process like replication, transcription and translation more difficult by intervening in them and thereby causing larval deformation, or even apoptosis and cellular necrosis. Although the PAH concentration in the stock solution was not calculated, in marine environments these elements can be found in different forms: dissolved, associated with the organic substance or as particles in suspension and, further, accumulated in the sediment (CELINO et. al., 2008).

The presence of derivatives of salicylic acid, a substance used as an anti-inflammatory and analgesic drug, but of an antimicrobial and insecticidal character (KUBO et. al., 1991; STUART et. al., 2000), can also have a toxic effect in the marine environment, as this compound can be converted into an organochloride, the chloride salicylic acid, that has mutagenic action and can also act in the hormonal control of some organisms deregulating their reproduction and development (BAGATTINI et al., 2006), capable, therefore, of having a toxic effect on sea urchin embryo development.

Further, another important compound in the light-stick formula is the di-n-butylphthalate solvent which, although not highly soluble in water even at low concentrations, even so causes irritation, burns and itching on the human skin; it is not of a carcinogenic character, but when swallowed causes gastrointestinal irritation, nauseas, vomiting, diarrhea, headaches and weakness (WILLIANS; BLANCHFIELD, 1975; TOMITA et. al., 1977; KAWANO, 1980; SCOTT, et. al., 1987; ELSISI et. al., 1989). In tests with aquatic organisms this compound has presented high toxicity in the Microtox test (TARKPEA et al., 1986) to sweet water algae and marine dinoflagellates (WILSON et al., 1978; YOSHIOKA et al., 1985; ACEY et al, 1987; O'CONNOR et al., 1989; KÜHN; PATTARD, 1990; 
YAN et al., 1995), as well as to marine microcrustaceans, mysidaceas, fairy shrimps, amphipodas and harpacticoid copepods (MAYER; SANDERS, 1973; LINDEN et al., 1979).

Generally speaking, the test with the stock solution acquired through the mixing of the liquids contained in the luminous attractor tubes with sea water, shows that there are compounds that are subject to transformation on mixing with sea water, leading to the toxicity of the sample. This should be seen as a warning, because these light-stick tubes are usually found on the coast and can cause serious harm to the marine flora and fauna, and also to human beings, who might inadvertently use the compounds described above in the attempt to cure diseases or develop a sun$\tan$.

Further in-depth study to establish the main kinds of chemical substances that are produced after their homogenization should be undertaken.

\section{ACKNOWLEDGEMENTS}

The authors wish to thank the NGO Global Garbage for their financial support in the scientific hike, particularly Fabiano P. Barreto and the "Capitães de Areia" (Sand Captains) for their guidance. Thanks to M.Sc. Elisete Paes e Lima (UNIMONTE-SP, Brazil) for the translation support.

\section{REFERENCES}

ACEY, R.; HEALY, P.; UNGER, T. F.; FORD, C.E.; HUDSON, R. A. Growth and aggregation behavior of representative phytoplankton as affected by the environmental contaminant di-n-butyl phthalate. Bull. environ. Contamin. Toxicol., v.39, p.1-6, 1987.

AMORIM, A. F.; ARFELLI, C. A. Estudo biológicopesqueiro do espadarte, Xiphias gladius Linnaeus, 1758, no Sudeste e Sul do Brasil, (1971 a 1981). Bolm Inst. Pesca, São Paulo, v.11, p 35-62, 1984.

AMORIM, A. F.; ARFELLI, C. A.; FAGUNDES, L. Pelagic elasmobranchs caught by longliners off southern Brazil during 1974-97: An overview. Mar.Freshwat. Res., CSIRO, Collingwood, v.49, p.621-632, 1998.

AZZARELLO, M. Y; VLEET, E. S. V. Marine birds and plastic pollution. Mar. Ecol. Progr. Ser., v.37, p. 295303, 1987.

AZEVEDO, V.G.; KOTAS, J. E.; DOS SANTOS, S. A pesca de espinhel de superfície ("Longline") na região SudesteSul- ano 1998. Relatório anual técnico-científico Programa REVIZZE - Score Sul. Itajaí, SC, 1999.

BAGATTINI, R.; SOUZA, C. B. de ; TOMA, I. N. MASCIO, P. di ; MEDEIROS, M. H. G. de ; BECHARA, E. ; LOUREIRO, A. P. de M. Toxicidade do conteúdo de atratores luminosos (light-sticks) a nível celular. Rev. Bras. Ciênc. Farmac., v. 42, p. 70-70, 2006.
BOFFETTA, P.; JOURENKOVA, N.; GUSTAVSSON, P. Cancer risk from occupational and environmental exposure to polycyclic aromatic hydrocarbons. Cancer Causes \& Control, v.8, p.444-472, 1997.

CELINO, J. J. ; VEIGA, I. G. ; TRIGUIS, J. A. ; QUEIROZ, A. F. S. . Fonte e distribuição de hidrocarbonetos do petróleo nos sedimentos da Baía de Todos os Santos, Bahia. Brazilian Journal of Aquatic Science and Technology, v. 12, p. 31-38, 2008.

ELSISI, A. E.; CARTER, D. E.; SPIES, I. G. Dermal absorption of phthalate diesters in rats. Fundam. appl. Toxicol., v.12, n. 1, p.70-77, 1989.

FURNESS, R. W. Ingestion of plastic particles by seabirds at Gough Island, South Atlantic Ocean. Mar. Pollut. Bull., v.14, p. 307-308, 1985.

HAMILTON, M. A; RUSSO, R. C. THURSTON, R. V. Trimmed Spearman-Karber method for estimating median lethal concentration in toxicity bioassays. Environ. Technol., v. 11, p. 714, 1977.

IVAR DO SUL, J. A.; RODRIGUES, O.; SANTOS, I. R.; MATTHIENSEN, A.; FILLMANN, G. Skin irritation and histopathologic alterations in rats exposed to lightstick contents, UV radiation and seawater. Mar. Pollut. Ecotoxicol., Hong Kong, vol. 1, p. 75, 2007.

KAWANO, M. Toxicological studies on phthlate esters. Inhalation effects of dibutyl phthalate (dbp) on rats. Japanese Journal of Hygiene, v.35, p. 684-692, 1980.

KUBO, I.; HIMEJIMA, M. Anethole, a synergist of polygodial against filamentous microrganisms. J. Agric. Food Chem., v. 39, p. 2290-2292, 1991.

KÜHN, R.; PATTARD, M. Results of the harmful effects of water pollutants to green algae (Scenedesmus subspicatus) in thecell multiplication inhibition test. Water. Res., v.24, n. 1, p. 31-38, 1990.

LINDÉN, E.; BENGTSSON, B. E.; SVANBERG, O.; SUNDSTRÖM, G. The acute toxicity of 78 chemicals and pesticide formulations against two brackish water organisms, the bleak (Alburnus alburnus) and the harpacticoid (Nitocra spinipes). Chemosphere, v.8, n. 11/12, p. 843-851, 1979.

MAYER, F. L. JR.; SANDERS, H. O. Toxicology of phthalic acid esters in aquatic organisms. Environ. Hlth Perspect., v. 3, p. 153-157, 1973.

MEINERTZ, J. R.; GRESETH, S. L.; GAIKOWSKI, M. P.; SCHMIDT, L. J. Chronic toxicity of hydrogen peroxide to Daphnia magna in a continuous exposure, flowthrough test system. Science total Environment, v. 392, p. 225-232, 2008 .

O'CONNOR, O. A.; RIVERA, M. D.; YOUNG, L. Y. Toxicity and biodegradation of phthalic acid esters under methanogenic conditions. Environ. Toxicol. Chem., v. 8, p. $-574,1989$.

PINHO, G. L. L. ; IHARA, P. M.; FILLMANN, G. Does light-stick content pose any threat to marine organisms? Environ. Toxicol. Pharmacol., v. 27, p. 155-157, 2009.

PRÓSPERI, V. A.; ARAÚJO, M. M. S. Teste de toxicidade crônica de curta duração com Lytechinus variegatus Lamarck 1816 e Echinometra lucunter, Linnaeus 1758 (Echinodermata: Echinoidea). In: NASCIMENTO, I. A; SOUSA, E. C. P. M.; NIPPER, M. (Ed.), Métodos em ecotoxicologia marinha. Aplicações no Brasil. São Paulo: Artes Gráficas e Indústria Ltda , 2002. p. 99-110. 
RESGALLA JÚNIOR, C.; LAITANO, K.S. Sensibilidade dos organismos marinhos utilizados em testes de toxicidade no Brasil. Notas téc. FACIMAR - Rev. Fac. Ciênc. Mar, Itajaí. v.6, p.153-163, 2002.

SCOTT, R. C.; DUGARD, P. H.; RAMSEY, J. D.; RHODES, C. In vitro absorption of some o-phthalate diesters through human and rat skin. Environ. Hlth Perspect., v. 74, p. 223-227, 1987.

SHAW, D. G.; MAPES, G. A. Surface circulation and the distribution of pelagic tar and plastic. Mar. Pollut. Bull., v. 10, p. 160-162, 1979.

STOREY, K. B. Oxidative stress: animal adaptations in nature. Braz. J. med. biol. Res., v. 29, n. 12, p. 17151733, 1996.

STEVANI, C. V.; BAADER, W. J. O sistema quimiluminescente peróxi-oxalato. Quim. Nova, v.22, p.715, 1999

STUART, A. E.; BROOKS, C. J. W.; PRESCOTT, R. J. Repellent and antifeedant activity of salicylic acid and related compounds against the biting midge, Culicoides impunctatus (Diptera: Ceratopogonidae). Entomol. Soc. Am., v.37, p. 222-227, 2000

TARKPEA, M.; HANSSON, M.; SAMUELSSON, B. Comparison of the Microtox test with the $96-\mathrm{hr} \mathrm{LC}_{50}$ test for the harpacticoid Nitocra spinipes. Ecotoxicol. Environ. Saf., v.11, p.127-143, 1986.

TOMITA, I.; NAKAMURA, Y.; YAGI, Y. Phthalic acid esters in various foodstuffs and biological materials. Ecotoxicol. Environ. Saf., v.1, p. 275-287, 1977

ULIANA, C. V.; RICCARDI, C. S.; YAMANAKA, H. Investigation on electrochemical behavior of peroxidase enzyme in the presence of hydrogen peroxide and 5aminosalicylic acid. Eclética quím., v. 33, n. 1, p. 57-62, 2008.
WANG, J. H.; BOLES, L. C.; HIGGINS, B.; LOHMANN, K.J. Behavioural responses of sea turtles to lightsticks used in longline fisheries. Anim. Conserv., v.10, p.176, 2007.

WEHLE, H. S.; COLEMAN, F. C. Plastics at sea. Nat. Hist. v. 92, p. $20-26,1983$

WHO (World Health Organization). Selected NonHeterocyclic Polycyclic Aromatic Hydrocarbons. Ipcs (International Programme On Chemical Safety). Geneva: Who, 1988.

WILLIAMS, D. T; BLANCHFIELD, B. J. The retention, distribution, excretion and metabolism of dibutyl phthalate-7- ${ }^{14} \mathrm{C}$ in the rat. J. Agric. Food Chem., v. 23, n. 5, p. 854-858, 1975

WILSON, W. B.; GIAM, C. S.; GOODWIN, T. E.; ALDRICH, A.; CARPENTER, V.; HRUNG, Y. C. The toxicity of phthalates to the marine dinoflagellate Gymnodinium breve. Bull. environ. Contamin. Toxicol., v. 20, n. 2, p.149-154, 1978.

YAN, H.; YE, C.; YIN, C. Kinetics of phthalate ester biodegradation by Chlorella pyrenoidosa. Environ. Toxicol. Chem., v.14, n. 6, p.931-938, 1995.

YOSHIOKA, Y.; OSE, Y.; SATO, T. Testing for the toxicity of chemicals with Tetrahymena pyriformis. Sci. total Environ., v. 43, n. 1/2, p.149-157, 1985.

(Manuscript received 2 March 2009; revised 11 November 2009; accepted 03 March 2010) 